\title{
John Locke, the Early Lockeans, and Priestcraft
}

\section{Mark Goldie}

Churchill College, University of Cambridge

\begin{abstract}
The term 'priestcraft' became fashionable in the 1690s. This essay explores its use among the anticlericals in John Locke's circle and examines the critique of priestcraft in Locke's own Reasonableness of Christianity (1695). The commentaries and church histories, in correspondence and published treatises, of Benjamin Furly, William Popple, Damaris Masham, William Stephens, and Sir Robert Howard are examined. The Lockean circle remained committed to Christian revelation and, for the most part, to a reformed Church of England, and it is argued that it is mistaken to identify the critique of priestcraft with deism and the subversion of Christianity. The polemical critique of the priestly deformations of Christianity, though often scabrously hostile to clergies, served the ecclesiastical and political cause of post-Revolution latitudinarian Anglicanism. The Lockean circle was committed to constructing a Church Whig ecclesiology.
\end{abstract}

Keywords: anti-clericalism, Church of England, civil religion, ecclesiology, Locke, priestcraft, Reasonableness of Christianity, sacred history.

The word "priestcraft" came into fashion in the 1690s. ${ }^{1}$ It was destined to have a conspicuous career in the lexicon of the Anglophone Enlightenment, encapsulated in Richard Baron's compilation, Pillars of Priestcraft Shaken (1752). The word appears just once in Locke's oeuvre, in The Reasonableness of Christianity (1695), yet the character of that book, appearing amid a provocative group of contemporaneous treatises on the malformations of religion, ensured that its author was ineluctably drawn into a vortex of controversy surrounding the new word in vogue. ${ }^{2}$ His friends used the word in correspondence with him; the authors of admiring tracts believed he had made a signal contribution to exposing priestcraft; his critics accused him of abusive hostility to the clergy; and his library contained some of the earliest works to use the term in their texts and titles. It is customary, in scholarly considerations of the Reasonableness, to dwell on the intractable matter of Locke's alleged Socinianism, and on the entanglement of its reputation in the deism of Charles Blount's Oracles of Reason (1693) and John Toland's Christianity not Mysterious (1696). ${ }^{3}$ The present discussion addresses rather its anti-clericalism, and hence ecclesiology rather than theology, and a circle of authors who were close to Locke both personally and in theological temper. ${ }^{4} \mathrm{~A}$ discussion of Locke's anti-clericalism ideally demands a survey of all his writings, and particularly the Letter Concerning Toleration, but I here examine the Reasonableness and its reception. $^{5}$

\section{The Lockean anti-clericals}


In 1700 Locke received an unsolicited letter from John Hardy, a twenty-year-old student preparing for the Presbyterian ministry at the Dissenting Academy at Oswestry in Shropshire. It was fan mail from an admirer, a "poor worm" who obsequiously sought guidance from a "large soul," and who announces that he has had a number of "scruples solved ... in many points by your works." Hardy plainly had in mind chiefly the Reasonableness of Christianity, and he had no compunction about presuming that Locke was the author of that anonymous work. That a trainee clergyman, who wished to enter that profession "pure and undefiled", should seek theological satisfaction from Locke cast the philosopher in the role of lay priest. ${ }^{6}$ In wishing to settle his mind about that "grand controversy ... whether Christ ... is properly God from all eternity," Hardy pointed to the furore over the Trinity and Christ's true nature which dominated theological literature in the 1690s. It was naïve of him to imagine he could induce Locke to commit himself on the most fraught and dangerous issue of the moment, not least because, as he himself added, his search in Scripture could "find little in favour of the affirmative at first sight." In other words, poor Hardy suffered from doubt about whether Christ was fully divine. He complained that most attempts towards the truth of the matter were mired in "terms of art and unintelligible vain janglings of words." Indeed, he despaired of any cleansing of the Augean stable of contemporary theology, for "I'm sure you know the world and the great trade of priestcraft (in fashion in every church) better, than to think that ever they will throw away all their narrow notions of man-made divinity ... and receive instead of it true and free reasonable religion." Hardy is one of several of Locke's correspondents who used the new word in vogue. He plainly hoped that the Reasonableness would be among the salient contributions to what limited hopes he had that the stable of theology might be cleansed of its mire. ${ }^{7}$

Locke did not know Hardy and apparently did not reply. But some of his intimate friends similarly believed that his writings were contributions to the struggle against "priestcraft". The most persistent and raucously anti-clerical voice within his immediate circle was that of Benjamin Furly, a flourishing textile merchant of Rotterdam. His correspondence with Locke merits examination, not least because he is so frank and rumbustious an interlocutor. Through him we can characterise several of the lineaments of contemporary anticlericalism. Author, bibliophile, philanthropist, and generous host, his home and library were meeting places for English, Scottish, Irish, and Continental scholars. He numbered among his guests Algernon Sidney, Toland, and the third earl of Shaftesbury. During Locke's exile in the 1680s Furly had provided him with a refuge. The two men corresponded until Locke's death, though they never met again after Furly's final visit to England in 1689-90. ${ }^{8}$

Furly was a Quaker in the process of renouncing Quakerism. What follows may seem digressive, given that critics of the Reasonableness assumed its target was the clergy of the Church of England, and that Quakerism was apparently the least clerical of all forms of Christianity. But it is important to grasp that, for Locke and his circle, "priestcraft" was a tendency within all organised religions, and that it manifested itself not only in the creedmaking of hierocratic churches but also in practices of religiously-inspired incivility, often associated with the puritan sects. ${ }^{9}$

Furly had been an associate of George Fox and other Quaker founders in the 1650s and 60s, and latterly a friend of William Penn, with whom he collaborated in promoting the colonisation of Pennsylvania. Quakers renounced all vestiges of settled ministry and were hostile to tithes. They were particularly apt to identify the ghost of popery in any form of 
institutionalised religious authority. Furly had, however, by the early 1690s, become disillusioned, finding that even this "Society of Friends" was prone, as it settled into denominational fixity, to acquire its own prescriptive orthodoxies. He was, furthermore, disturbed by Quaker incivility, its sectarian disregard for ordinary forms of public decorum, by which uncouthness towards non-Friends was obligatory. He could no longer find it in good conscience necessary to continue refusal of "hat honour," that famous insubordination by which Quakers denied deference to earthly hierarchies, through refusal to doff their hats to social and magisterial superiors, a practice he had himself vigorously defended in the $1660 \mathrm{~s} .{ }^{10}$ Such marks of renunciation of worldliness could amount, he now thought, to a violation of "civil conversation". The crisis came when the funeral of his beloved first wife was denounced by fellow Quakers for its pomp (and it was said so in faraway Pennsylvania); and when he - and more emphatically, his second wife-insisted on allowing their children to make their own life choices, and particularly to pursue the vanity of worldly learning. This touched Locke closely, for young Arent Furly was a special favourite of his, who passed under Locke's educational guidance. Furly's apostacy was met by Quaker wrath, which bore all the marks of the censorial high-handedness that seemed to infect every Christian denomination without exception. They were abusive too: Furly was, they said, a dog returning to his vomit, wallowing in the filth of worldliness.

In his letters to Locke, Furly unburdened his misgivings. He said that he could not allow Quakers to condemn as wicked and ungodly "all the sober serious Christians in the world besides themselves." Whereas he had once loved the Quakers, for their "conversation," for making their meetings open to all, and for dispensing with creedal articles and subscriptions, and "things called sacraments," he could no longer do so now they had acquired the universal "knack of member-making" and member-breaking. After the crisis, Furly was a man of no religious affiliation, beyond that of "mere Christian." He now found himself guyed by another denomination too. He married a new wife, Susanna Huys, of the Dutch Reformed Church — "no superstitious bigot ... witness her espousing me"-whom he admired for her courage in brushing aside clerical warnings that her proposed match with a "libertist and heretic" endangered her salvation. ${ }^{11}$

Like Hardy, Furly used the word "priestcraft" in correspondence with Locke. Sometimes he meant Catholicism, specifically that of France, a country where civil tyranny was consecrated by priests. But it could mean all churches. Writing in 1694, Furly wished that Locke and he were together in company, so that they might "frame such a society, as we have sometimes spoken of, and you now again mention." We do not know what Locke had mentioned (and Furly was more given to utopianism than his friend), but Furly's remark follows his praise of Susanna's freedom from "narrow spirited catechisms, systems, and confessions," and his condemnation of Pennsylvania's persecution of George Keith, another Quaker defector. ${ }^{12}$ There then follows an eloquent passage: "In the meanwhile, we must be content to stumble on, as well we can, and expect what providence will next hand forth to us; for I am fully assured that priestcraft will fall, and cannot stand long against the light, that has so far opened men's eyes to see through the tiffany cover of their fulsome authority." ${ }^{13}$ As elsewhere in Locke's conversations, there is here an evanescent apocalypticism, a halfexpectancy that a final solution will providentially unfold, in an era when true religion will reign. In a later letter, the utopian dream lingers on: how hard it is to "get a society so free, as you and I would gladly see, and help propagate in the world." No less eloquent is the vision 
Furly had when he was high on laudanum, a drug to which he was addicted: "I do mighty things, I make the Jacobites wise, ... I break down tyranny in church and state, I destroy all sects ... and erect a church universal." Then he sobers up, and knows it was but a "fool's paradise." The new word in vogue turns up again when Furly recommends to Locke a young travelling scholar from Leipzig, Gottfried Olearius (who may later have translated Locke's Letter Concerning Toleration into German), whom he describes as "free, learned, and ingenuous, [who] sees the priestcraft sufficiently ... and as such I know will be acceptable to you." 14

Furly enjoyed the coffeehouse game of multiplying epithets for priests. Clergy were "coxcombs," "ghostly fathers," "hirelings," "black-coats," "phylactery-men," "chemarims". 15 He often allies the word "trade" with the clergy. It was axiomatic for him that spiritual "slavery and bondage" was as bad under Protestantism as under Rome. Furly was allergic to the most minimal theological jargon, refusing "the canting word church," and referring to a "triplicity (I will not use the Athanasian word [Trinity]"), ever eager to "expose those two words 'church' and 'heretic', as two of the most pernicious words that have for above one thousand years obtained amongst mankind." Furly had a fund of irreverent stories. Proud that his son Arent inherited his own anti-clericalism, twice he told of young Arent going to a church service out of curiosity, presumably at the local Reformed kirk; when asked what he had seen, he replied that a man spoke from a great "kackstoel" (a child's close-stool). Delighted at this response, Furly agreed that preaching "indeed ... is shitten work, and I hope he'll learn it to be such." Another, much darker, story is of a respected local clergyman, full of pompous piety and starched gravity, discovered to be raping girls in his care, one fourteenyear-old "so treated ... that the child could not with ease sit." The clergyman was fearlessly exposed by a local magistrate, but disgracefully defended by fellow clergy, who accompanied him to a serene execution whispering sanctimonious assurances that he was still saved. ${ }^{16}$

Furly had epigrams too. The clergy "side with the strongest party right or wrong ... it's a maxim seldom fails the men of that coat." He could share obscure witticisms that Locke would recognise as borrowed from Samuel Butler's Hudibras. He adopted the familiar stratagem of unmasking Christian liturgy by showing that it was a pagan inheritance: the two sacraments (of the Protestants) were "purely pagan institutions, hatched by the juggling Egyptian priests." And he sent Locke a ditty, which Toland would reproduce in his Letters to Serena (1704) as "lines which are in everybody's mouth": "Natural religion was easy, first and plain. / Trade made it mystery, and offerings gain. / Then ceremonies and sacrifices were prepared / The priests eat roast meat, and the people stared." It is no surprise that Furly was initially much taken with Toland, that most artfully plausible of young men, who was introduced to him in 1693 as a former papist, now training for the Presbyterian ministry. This young man "having once cast off the yoke of spiritual authority, that great bugbear ... could never be persuaded to bow his neck to that yoke again, by whomsoever claimed." Furly enjoyed making up mock inverted prayers. From "the great highwaymen of the church ... libera nos domine." Sometimes his exclamations were simple enough: "God preserve King William and Queen Mary from church bogs."17

Very few of Locke's letters to Furly survive, so we have only a fragmentary sense of his attitudes when confronted by his friend's barrage of jaunty rudeness about churches. Locke was no Quaker, and he was apt to find Quakers foolish dogmatists, naïve illuminati, pointlessly sectarian, and wretchedly uncivil; he cannot but have been glad that Furly 
renounced them. ${ }^{18}$ We can guess he readily supported the doing of "hat honour" when Furly asked his opinion of it. It is clear that Furly took Locke to be a sympathetic auditor for his pasquinades on the antics of the religious. We have hints of the tone of Locke's responses in the missing side of the exchange, such as when Furly reports Locke as remarking on what "displeased the ruling scribes and pharisees." 19

It is hard to find what might, for Furly, be left of the Christian church once all the "catechisms, systems, and confessions" are put aside. He thought the matter was simple: what is left is love of God and of our neighbour. We can surmise that Locke, in a missing letter, demurred at Furly's naivety about the possibility of so etiolated a religious society. When people share a common vision, however slight, they need some outward and visible sign of their communion. Furly, having said, more or less, that to be a member of anything was to be a slave, added a hesitation which probably catches something Locke had said to him: "whether you understand so much of this society, if it may be so called that are under no compact one with another: I know not." ${ }^{20}$ For Locke, a society (a union of the like-minded, joined in common commitments) must have some formal and material existence, a system of shared symbolic action, a means of acting as one corporation: in sum, a body of people who form a compact to create a corporation. Furly had gone beyond that. It was later said of him that he was "a pious Christian, but of no church, nor goes to none." 21

If Furly seems to have moved beyond the Church, it is worth noting some of his sources. When he calls the sacraments mere echoes of Egyptian "juggling," he says he can prove this out of "Marsham" and "Spencer," yet these were pre-eminent Anglican students of sacred history. ${ }^{22}$ He draws on scriptural scholarship to argue that the phrase, imputed to Christ and crucial for the sacrament of the eucharist, "do this in remembrance of me," is only to be found in Luke's Gospel, where it is, he says, a probable later and erroneous insertion in the text. To press this point, he asks Locke to get a transcript of the relevant passage in the Codex Bezae in Cambridge University Library; Locke does so, and the transcript shows the phrase is indeed missing. ${ }^{23}$ Furly's scepticism is thus articulated through the tradition of Reformed scriptural criticism. If he is the most persistently raucous anti-clerical in Locke's circle, he was nonetheless indebted to long traditions of Christian humanist scholarship. ${ }^{24}$

About another of Locke's colleagues, William Popple, we can be briefer, and the case serves to show that Furly was not an exotic outlier. Popple, author of several tracts on "reasonable" religion, translator of Locke's Epistola de Tolerantia, secretary of Locke's Dry Club, and whom Locke met daily in London at the Board of Trade in the latter half of the 90s, confided his indictment of priestianity to his private manuscript volume of verse, notably in his "Epistle to Eupolis" (1695). Popple's dissolution of the clerical estate was as fundamental as Furly's. He sketches a portrait of the clergy, for whom "religion [is] bought and sold"; they are men of "juggling, trumpery," who "harangue and prate," who "in Septenary paroxysm / Spews't forth against all heresy and schism," "their gospel's fundamental text, Compel." His remark that their crying down of "errors [in which] all is -ism" denotes a shrewd observation that practically every "ism" in the English language at that time was the name of a religious sect or creed. The clergy are quacks, magi, witches, mountebanks, "scaramouchios." He denounces the high churchmen's stupid cry of "the Church in Danger," under which flag "the black posse rose." He then turns to adumbrate his poem's heroic mission: "I ... priests unmask." He praises Quakers for their simplicity and priestlessness, albeit that they are given to "rhapsody" and "delusion." Other praise is reserved for Robert Boyle, "nature's late 
favourite," chiefly for the lectureship he founded by his will, which was designed to teach natural religion and a Christianity free of bigotry in all matters of "mere speculation." It is in the great lay priest, Boyle, and his lectureship, that Popple finds hope amid the stentorian bickering of the contemporary clergy. ${ }^{25}$ There is something unexpected here: an apparently outright deconstruction of the panoply of the Christian church finds its denouement in praise of a new pillar of Anglican churchmanship, the Boyle Lectures. By 1695 Richard Bentley had lectured on The Folly and Unreasonableness of Atheism, Richard Kidder (a future bishop) on A Demonstration of the Messias, and John Williams (another future bishop) on The Possibility, Expediency, and Necessity of Divine Revelation. ${ }^{26}$ We should hesitate before presuming that the enemies of priestcraft were deists or renouncers of the Church of England; most in Locke's circle were neither.

Popple used the word "priestcraft" in a letter to Locke in 1693, referring to a Huguenot tract he admired, recently distributed in London, whose author had been interrogated by the Bishop of London and consigned to Newgate jail. ${ }^{27}$ The quartet of interlocutors who use "priestcraft" in correspondence with Locke is completed by Andrew Fletcher of Saltoun, a writer latterly famous as a Scottish patriot. In a miscellaneously newsy letter of 1695 he remarks, "If you ask me what I am doing I shall tell you that I am tracing priestcraft from its first original in Egypt. Where I find likewise many other monsters but none so abominable." That is all, and apparently no such project eventuated. His published writings contain ritually Whiggish anti-clericalisms, against churchmen who are "never failing to confound things spiritual with temporal." ${ }^{28}$ Fletcher's letter does, however, point to a larger scholarly terrain among Locke's contemporaries, the historical investigation of the character of Egyptian religion, as the putative source of all priestly corruption, and most especially that which seeped into Judaism and popish Christianity. This project would be pursued by the third earl of Shaftesbury in his Characteristics (1711), and is brilliantly captured in epitome in its engraved frontispiece, which shows the passage of idolatry from Egypt, through Judaism, to Catholic Christianity and beyond. ${ }^{29}$

Finally, within the household in which Locke lived, Damaris Masham wrote of "priestcraft" in the book she composed at about the same time Locke wrote the Reasonableness, and which she will have discussed with Locke. Her definition is that it is constituted by whatever "destroys all the duties and obligations of social life." Masham insists that we are designed for a "sociable life" and resists any reading of Christianity which encourages the dissociation of piety from our naturally conversable selves. A religion which withdraws us from common humanity cannot be authentically Christian. This is Masham's enlargement of a common anti-popish claim that the monastic and conventual life are inimical to the proper embodiment of holy living in the virtuous pursuits of the temporal world. ${ }^{30}$ If it is priestcraft to alienate Christianity from sociability then, in Masham, we are close to a conception of civil religion: Christianity, wrongly conceived, is the enemy of secular virtue, temporal flourishing, and our sociable nature.

\section{Locke's critique of priestcraft}

Not much of Locke's Reasonableness is dedicated to a critique of priests, and most of Locke's anti-clericalism is incidental and routine. There is a passage in which he apparently 
adopts a Democritan position, which could be found in Hobbes's Leviathan and in various places in Renaissance religious anthropology. Through fear and ignorance of dimly apprehended ghostly beings, Locke suggests, people in ancient times "gave them[selves] up into the hands of their priests," and "what dread or craft once began, devotion soon made sacred, and religion immutable." Later, he speaks of philosophers in the ancient world regarding "superstitious and idolatrous rites" and the ignorance of the "credulous multitude" as consequent upon the priestly doctrine of an afterlife, and so "suspected it presently of priestcraft." It is here that the cant word appears for the sole time in Locke's writing. ${ }^{31}$ Characteristically, he does not embark on an extended historical anthropology, of the sort to which contemporary scholars were committed. His chapters are dusted with commonplace, if rudely vehement, jibes against the "holy tribe," their "tricks," their "creeds and profitable inventions," the "lustrations" and "expiations" of their "pompous, fantastical, cumbersome ceremonies." And likewise against their "systems of divinity," "vain philosophy," "foolish metaphysics," and those "speculations and niceties, obscure terms, and abstract notions" which make it necessary to come to church by way of the academy. ${ }^{32}$ Locke would continue in a similar vein in the Vindications of the Reasonableness. He described his critic John Edwards as "bawling for his fashionable and profitable orthodoxy," and turned the tables on accusations of using vogueish vocabulary by insisting that the words "atheism" and "heresy" were themselves "invidious names in fashion," designed by the priests "to make themselves hearkened to, as men in earnest in religion." ${ }^{33}$

Much more sustained, however, is Locke's assault on the viciousness of the scribes, priests, and Pharisees who actively sought Jesus' death. Jewish blood-guilt was of course a deeply entrenched Christian theme; for Locke, Jewish pharisaism is the archetype of perverted priestliness. In his account, the whole of Jesus' ministry was shaped by the need to evade priestly vengeance against him. A central theme is that Jesus delayed until late in his ministry public affirmation of his messiahship. So dangerous was that doctrine in the context of Jewish subjection to Roman imperial rule, that Jesus kept it hidden, hinting at rather than affirming it. He taught his truth in obscure and allusive terms, until the last moment, through "parabolical," "figurative," "enigmatic," "circumlocutions."34 This theme of the Messiah's arcane secret is deeply at odds with his general insistence on the plain truth of the Gospel. ${ }^{35}$ The Jews either hoped to find a temporal king, a revolutionary who would lead them to deliverance and create a "glorious earthly kingdom," or they aimed to destroy an imposter who pretended to be the Messiah. Either way, Jesus wished not to provoke a premature truncation of his all too brief ministry. For Locke, Jewish priests are a constantly looming presence, seeking to ensnare and denounce Jesus. By contrast, he depicts the Roman secular magistrates as even-handed, and exasperated by the Jews and their fanaticism. Locke's Pontius Pilate is a sympathetic figure. ${ }^{36}$

More sustained, too, is Locke's account in Chapter 14 of the several corruptions of ancient religion which Jesus came to dispel. Here he encompasses the whole of ancient religion and not only the Jewish. This, we need to note, is a chapter in refutation of contemporary deism, and Locke succeeds in turning anti-clericalism against the deists, by showing that it was the flimsy hubris of ancient philosophy-of the advocates of reason-that bred clerical monstrosities by way of a reaction against the vanity and vacuity of secular philosophy. For Locke, undue faith in reason was a type of "enthusiasm". Contemporary deist claims for the great capacity of reason, Locke asserts, cannot be sustained in the face of 
history's evidence to the contrary, for the darkness of error and superstition, and its priestly manipulators, had, through time, overwhelmed the dim light of reason and its partisans. For all the wisdom of the Athenians, it was not the philosophers who had ruled, but "priests everywhere ... [who] secure[d] their empire," crowding the world with "wrong notions, and invented rites." Locke gestures toward an aristocratic conception of a rational elite, who, unlike the "vulgar," "multitude," "mob," and "herd," are not gulled by the designing priests. Yet the wise had been ignored, while the priests were revered. ${ }^{37}$ Nor, for the future, does Locke offer a theology of progressive enlightenment, in which modern reason outpaces ancient. Locke's Jesus came to save the world from priestcraft because the philosophers had failed to do so.

Locke reiterated this theme more schematically in 1698 in a memorandum he left unpublished, called "Sacerdos." Drawing upon Cicero's De natura deorum, there were, he says, two sorts of teachers amongst the ancients: priests and philosophers. The first promised "propitiation and atonement" of the gods through ritual observances; the second offered the rules of natural morality. The two camps were wholly contrasting: the first ignored ethics, while the second did not meddle with public religion. Here were two distinct castes acting upon two distinct "provinces of knowledge," revelation and reason. It was this perverse separation and alienation which Jesus resolved: the Messiah "reunited these two again, religion and morality ... which ought never to have been separated." Thus it was the ministers of the Christian religion who achieved a proper synthesis, and "assumed ... the parts [the roles] both of the heathen priests and philosophers." 38 The lives of pure idolatry and of pure reason were both failed projects, and the history of the ancient world provides evidence of the wreckage. Christianity it is which, if pure, satisfactorily recombines virtue with the divine. Any falling off from this union is a replication of pre-Christian corruption. Pre-Christian religion was wholly given over to ritual, and had negated virtue: plainly it was an archetype for any putatively Christian denomination in modern times which likewise displaced virtue with the idolatry of mere ceremonial.

Locke's phrase about "reuniting" might bring to mind Rousseau's later salute to Hobbes's civil religion for "reuniting the two heads of the eagle," the spiritual and temporal realms. ${ }^{39}$ The Lockean vision bears similarities. The task of the Christian reformer is to restore Jesus' own promise of reuniting two realms, the spiritual and ethical. In Locke the realm of the secular is a realm of natural morality rather than that of the civil commonwealth, although the latter, construed as public association, is the arena for the performance of the social virtues. In "Sacerdos" and in the Reasonableness Locke is not, on the whole, concerned with the specifically unpatriotic crimes of priestianity, its destruction of allegiance to the patria, that preoccupied Machiavelli, Hobbes, and Rousseau. ${ }^{40}$ Rather, he resolves ancient priestliness into three kinds of corruption, which made Jesus' mission imperative for the saving of benighted humanity: superfluous creeds, baroque ceremonialism, and moral viciousness. It would not be difficult for his readers to detect in these an implied critique of modern churches. It was precisely this insinuating, implicative sort of historical writing about ancient priestcraft which infuriated contemporary churchmen, for the critics rarely had as their overt polemical target church establishments in the present. When Locke was accused of attacking contemporary clergies, he insisted that he was referring only to the Jewish and heathen priests of the ancient world. ${ }^{41}$ It was a scarcely persuasive defence, and he joined practically every other anti-clerical author in hiding behind allegories of ancient religion. 
It might be thought incumbent on an anti-clerical who remained, as did Locke, a member of the Church of England to give some substance to an alternative ecclesiology, a theory about the proper character of a Christian church. What, for Locke, constituted the church under a reformed regime of priestless Christianity? The Reasonableness provides slim guidance; it is not, admittedly, its purpose, which is to establish the fundamentals of the Christian faith. Even so, the lacuna is exasperating. When he cites the classic scriptural text in which Jesus authorised his church, in the promise to Peter that "upon this rock I will build my church" (Mt. 16: 18), he offers no ecclesiological consequence, no ministerial office, still less a hierarchy of offices. He says only that the church is built upon Peter's profession of faith that Jesus was the Messiah. ${ }^{42}$ When, in regard to worship, he castigates "pompous ... ceremonies," he says that Jesus brought us "plain" worship. Here he seems straightforwardly ultra-puritan in his radical anti-formalism. ${ }^{43}$ Under Jesus, there is no place for "magnificent temples, and confinement to certain places, [which] were now no longer necessary for his worship; which by a pure heart might be performed anywhere." ${ }^{44}$ This is an arresting claim and seems Quakerish, or Pietist, in its extreme anti-formalism, though it could be argued that it is indebted to a broader Erasmian, including even Catholic Counter-Reformation, strain of emphasis on infusing piety into the conduct of our everyday temporal callings. Locke secularises the church by sanctifying the secular. This was no more than the ambition of countless Protestant and Catholic reformers. To repeat his telling phrases, Jesus' church cannot be "confined to certain places," because "a pure heart might be performed anywhere."

More locally, in the religious politics of the 1690s, Locke joined with those who regarded the Restoration church as having been grievously misguided in its pastoral priorities, persecuting those who rejected the formalities of Anglican liturgy and governance, while indifferent to an ugly sea of libertine immorality. The early 1680 s, the years just before the Revolution, had seen the greatest pitch of coerced Anglican conformity. The Revolution was an opportunity for a pastoral revolution, for a new focus on the "reformation of manners." There is a passage in the Reasonableness which is hard not to read as parallel to the widespread complaint voiced by the new Reformation of Manners movement, but couched, as always, in terms of ancient priesthoods. The priests made people "frequent the temples: everyone went to their sacrifices and services: but the priests made it not their business to teach them virtue. ... Lustrations ... were much easier than ... a steady course of virtue; and an expiatory sacrifice ... was much more convenient than a strict and holy life."45

Locke did not dissolve the church as a formal association. He makes clear that religious assemblies and "public acts of worship" are necessary. He seems to fall back on an elementary Aristotelian insight that any group of people which shares a common purpose will need a visible and outward expression of their communion. This is what Christian theology calls koinonia. While Locke is emphatic about adiaphora, the indifference of this or that liturgy, he also echoes a familiar theme in conformist argument in remarking that "decency, order, edification, [are] to regulate ... public acts of worship." This recalls the familiar conformist citation from 1 Corinthians: "Let all things be done unto edifying." We are to "shut out indecency and confusion ... [from our] assemblies," Locke writes. ${ }^{46}$ Here the Pietist pure religion of the heart is countered by implied distaste for, and disbelief in, the sectary's abandonment of all set forms, all adherence to shared performance. In "Sacerdos" Locke again refers to worship that has been purged of "pompous rites" but remains regulated by what "decency and order required in the actions of public assemblies." 47 A church has good 
reason to be uniformitarian, for in the shared conventions of ritual we act out our common purpose, our solidarity as children of God. There can be no forced church membership, but voluntary membership does entail submission to a common discipline. It seems that Locke wished to prevent the religion of the "pure heart" from becoming merely, and potentially dangerously, inward, private, extempore, and solipsistic. We are associative beings. In using the language of "decency and order" and that which is "edifying," he deliberately places himself in the mainstream of long-established Anglican arguments for conformity, to which he had given emphasis in his discussions of religious worship since his youth. ${ }^{48}$

\section{The priests' critique of Locke}

The anti-clericalism of Locke's Reasonableness was seized upon by its clerical critics. His most formidable enemy, the Cambridge divine John Edwards, remarked, in a book licensed by the University, that Locke showed "disdain of the ministry ... especially the clergy of the Church of England." "Antipathy against priests," he wrote elsewhere, was one of the "qualifications in order to being his converts." Locke "rudely vilified" the clergy. ${ }^{50}$ The current flood of anti-clerical literature provoked the clergyman Richard Willis to produce a periodical essay, The Occasional Paper, which ran for ten issues in 1697-8. ${ }^{51}$ Two issues were devoted to critiquing the Reasonableness, while others addressed Toland's Christianity not Mysterious, the anonymous Lady's Religion (1697), and Matthew Tindal's Essay Concerning the Power of the Magistrate in Matters of Religion (1697), all of them, Willis says, being of a "party" which cannot "write a book without this topic of priestcraft." Willis's first and fifth papers have a running theme of Locke's prejudice against ministers of religion. The prejudice is implicit in Locke's doctrine that Christianity has one "sole article," that Jesus is the Messiah, for it follows that "stickling for the rest [of the creed] is only sect and party, and priestcraft, and narrowness of spirit." It is explicit in Locke's history of religion in Chapter 14, where Willis cites him speaking of what was done by "priests everywhere, to secure their empire," and of the inventions of the "designing leaders" of religions intended to gull the "herd." Willis protests that although these remarks refer to heathen ministers, Locke's "air and language" imply all priests. When Locke protested that he was not anti-clerical, Willis redoubled the claim, citing Locke's account of heathen priests elevating ceremonialism above moral discipline, a charge which, any reader knew, was constantly made by post-Revolutionaries against the attitude of the Restoration Church. ${ }^{52}$ Locke, he complains, cannot therefore avoid the charge that he provides ammunition for what is in "the mouth of every libertine, that priests of all religions are the same." $" 53$

Willis takes Locke's depiction of the false priest as implying an alternative vision of a priestless world, a radical version of the Reformation cry of "the priesthood of all believers" -although, properly speaking, Locke rejected the literal idea of priesthood altogether. ${ }^{54}$ In the Lockean post-clerical world, writes Willis, "every man may be his own priest." Hence, Locke implies an ecclesiology in which there would be no distinction between laity and clergy, no office of priest "appointed" by Christ for the "instruction and government of his church." Willis's censure was delivered as if he were speaking to a Quaker or other sectary. Indeed, in one of his papers he refers to the Quakers' founding father, George Fox, as holding 
a notion of priestless Christianity. Locke's anti-clericalism provokes from Willis an exposition of standard Christian (episcopalian) ecclesiology: Christ's singling out of the twelve apostles and seventy disciples as the primordial bishops and presbyters, a hierarchy made more visible in the Epistles of St Paul to Timothy and Titus, where the laying on of hands marks the means of apostolic succession. To the priestly office Christ gave authority to teach, discipline, and censure, and to the laity was given the duty to maintain the clergy, whose stipendiary support is prescribed in Scripture. ${ }^{55}$

While Locke was generally accorded the dignity of consorting, intellectually, with serious writers on theological subjects, albeit including writers of pamphlets, he was sometimes allied with a broader demotic culture of anti-clericalism, the raillery of the coffeehouse wits. (The parallel with Hobbes's lionising by the Restoration wits is marked.) Locke, wrote Edwards, is "caressed and admired by the men of wit about the town who make it their business to banter Christianity, and (in a word) [he is] cried up by the atheistical and debauched, who as concernedly rally all religion as the late field-officer doth priests." $\mathrm{He}$ further speaks of the "town sparks," who complain against "systematic-men and ... mysterymen.",56

\section{Histories of priestly religion}

If Locke's critics placed him among other contemporary enemies of priestcraft, so too did his admirers. The most explicit contemporary contextualisation of the Reasonableness as a contribution to the sociology of clericalism occurs in William Stephens's Account of the Growth of Deism (1696). Stephens belonged to that as yet tiny phalanx of Anglican clergymen who were pronounced Whigs. He acquired the rectory of Sutton in Surrey from the hand of Lady Ann Mason, wife of the arch-Whig Lord Brandon, earl of Macclesfield. He belonged to Locke's Dry Club, a salon for deliberation on philosophical, religious, and ethical matters; and was a dinner guest, correspondent, and perhaps literary assistant of the third earl of Shaftesbury. In 1700, after outraging the Tories in the House of Commons by a sermon that used Locke's Two Treatises, he was offered a benefice by Locke's patron Charles Mordaunt, earl of Peterborough. ${ }^{57}$

Deism, which Stephens defines as "a denial of all revealed religion," is, he admits, spreading. But he insists that he himself is no deist and that his task is to explain why churchmen have only themselves to blame for its growth. In his account, the widespread disillusionment with Christianity among the English laity was bred less of philosophical doubt than of dismay at priestcraft. The deists have "conceived so great a prejudice against the Christian faith, from the behaviour of the clergy." He purports to record the opinions of several unnamed gentlemen, while adopting the authorial persona of an embarrassed defender of the wayward Church of England. His tract is valuable for its interlacing and connecting of multiple objections against clerical turpitude: creedal impositions, enforced religious conformity, and the political theory of Toryism. Although it is only the Reasonableness that is explicitly named among Locke's works, Stephens stands firmly in Lockean territory on all fronts. He defends the Toleration Act, reproaching ministers for preaching against it; denounces the continuation of the Test Act, by which Dissenters are excluded from public office; and deplores pre-Revolution divine right doctrine and post-Revolution de facto 
doctrine, which deprive King William of his only true ground of legitimacy, "the consent of the people." 58

As an overt admirer and expositor of Locke's Reasonableness, Stephens firmly wishes to insist that that book upholds divine revelation. Indeed, an "old acquaintance" of his had returned to the Church upon reading Locke's book, together with Jean Le Clerc's Five Letters Concerning the Inspiration of the Holy Scriptures (1690). This gentleman had always thought the Bible an invaluable guide to morality, but now, by Locke's book, "was convinced, that he was indebted to revelation more than he thought," and was persuaded too that miracles were true and necessary in order for Jesus to acquire legitimacy to beat down the entrenched authority of pharisaic ceremonialism. Thus he now saw that Jesus himself came to deliver a "priest-ridden people" from clerical oppression. This gentleman interlocutor now sets out the apparently Lockean terms on which he is prepared to re-embrace the established Church. He will conform to parish worship and uphold the maintenance of the ministry, but will not exclude himself from attending Dissenting worship also, since one could be a member of any church which upheld the "faith and practice, contained in the book ... the Reasonableness of the Christian Religion." He continued to doubt "whether any church was sufficiently reformed from popery," and to think all churches are riddled with doctrines which cannot be found in the Gospels. He would no more give up his reason to the Church of England than his senses to the Church of Rome; yet he would be of the Church of England, while not of the Church party. He feared "the clergy would always distinguish between church and state." This last remark is suggestive of the compatibility between a commitment to pluralist toleration and an idea of civil religion: a church must be understood as the citizen body at prayer, not as an institution claiming parallel and autonomous authority. This point is elaborated in the claim that "our Protestant high priests do all of them rival the sovereign power." Stephens protests that the doctrine of the divine right of the church is as sedulously preached as the divine right of kings, but that, since the cross is above the crown, so the church will in the end aim to overawe the crown. There is here an Erastian temper, not one that requires the state to define or absorb the church, but one which recognises that the state must use its power to restrain churchmen who seek to establish for the church a public authority over citizens. ${ }^{59}$

Stephens's tract replays all the familiar anti-clerical topoi. The Christian ages have been full of the "odium theologorum" and "church history is chiefly a relation of churchmen's wrangles"; Englishmen used to go on the Grand Tour to inspect the corruptions of popery but now "there is no need of going over the water to discover that the name church signifieth a self-interested party"; the Civil Wars were provoked by the "insolence" and bickering of Laudians and Presbyterians; the consensual restoration of Charles II was wrecked when the Act of Uniformity reduced him "to be king of the Church party"; the Restoration Church preferred rather to enforce liturgical conformity than moral discipline; the Church of the 1680s betrayed the liberties of their countrymen; and post-Revolution churchmen usurp King William's legitimacy by withholding his de jure right, and hence the Revolution has but "increased men's prejudices against the clergy." 60

As well as venerating Locke and Le Clerc, Stephens offers two other books which he upholds as belonging to the same intellectual enterprise, the one theological, the other historical, both of which "with great exactness ... distinguished between religion and priestcraft." Sir Matthew Hale's discourses concerning religion set out Christian essentials 
shorn of "circumstantial appendages," while Sir Robert Howard's History of Religion (1694) narrated the false accretions upon the simple essence of true religion. ${ }^{61}$ The latter treatise, he reported, had characteristically met with "priestly insolence and malice from the pulpit," in Whitehall chapel by Francis Atterbury - who was at this time flexing his muscles for what would prove a long career as the leading high church champion. ${ }^{62}$ Stephens, then, firmly placed Locke's Reasonableness within the currently vibrant school of Whig analyses of priestcraft, while simultaneously asserting its adherence to Christian revelation and imputing to it a commitment to low church ecclesiology in the developing struggle between high and low church factions.

The book which had the greatest panache among the post-Revolution exposés of priestcraft was Howard's History of Religion. A stylishly written and elegantly printed little book, its title page lacked author or publisher, but Howard was quickly identified. He was an ardent Revolution Whig Member of Parliament, nicknamed "Sir Positive," a Privy Councillor from 1689, an assertor of the "deposition" and "election" of kings, and a constant scourge of Tory principles and persons. Here was a prominent lay gentleman-scholar setting out a formidable critique of "how religion has (from the beginning) been managed by [the] priestcraft of the heathens." He enters the usual caveat that his argument does not apply to Reformed Christianity, but his indictment is shockingly panoptic. Howard skilfully epitomises multiple strands drawn from earlier anti-clerical traditions. There is a humanist assault on officious human authority in the name of rational analysis: people should be "daring to use their own understandings." There is distaste for baroque speculative metaphysics, the "impious temerity of the learned" in constructing "a plan of divinity from Aristotle's philosophy." There is a Marvellian narrative of the birthpangs of perverted creed-making in the fourth-century quarrel of the Arians and Athanasians, the homo-ousians and homoiousians, and of the hideous irony that Christians, "no sooner freed" from the miseries of persecution by Diocletion, "practised upon others all the mischiefs and crimes which [they] themselves have suffered." "T3 There is a moral revulsion against the life-denying and unnatural fetishes of ascetics and martyrdom-seekers; yet equally a puritan's aesthetic abhorrence of the gaudy, sensuous, operatic vulgarity of hyper-ceremonialism, its "oblations," "lustrations," and "expiations"; and an Arminian distaste for theologies grounded in craven appeasement of divine wrath. There is a humanitarian's shock at the rivers of blood spilt by warring Christians and persecuting inquisitions. There is the tolerationist motif that coercion cannot induce inner conviction: "persecution can be no argument to persuade." There is an anthropological disclosure of narratives and archetypes to be found serially in the mythologies of all ancient religions. Here he parallels Cham's discovery of Noah's nakedness with Tiresius's of Minerva's and Actaeon's of Diana's; he remarks that saint worship and martyr shrines bear resemblance to pagan cults of the deified dead; and observes that the Elysian Fields of the Greeks match the paradises of virgins and ganymedes offered in Islam and in paganised versions of Christianity. ${ }^{64}$

Citations from Plato, Virgil, Seutonius, Hermes Trismegistus, Cicero's De natura deorum, and the Old Testament march together. Principal modern sources include Grotius, the French annalist François de Mézerey, the Huguenot scholar Samuel Bochart's Geographia Sacra (1646), Bishop Gilbert Burnet's Travels (1687), for evidence of Romish superstition, and especially the work of two Anglican churchmen, William Outram, his De sacrificiis (1677), and John Spencer, his De legibus Hebraeorum (1683-5) — "from whom I borrow the 
most I say on this matter" of Jewish ceremony. Strikingly, he praises the great Revolution archbishop, John Tillotson, whose sermons he proclaims as the essence of a properly reformed Christianity. ${ }^{65}$ This is anti-clericalism built upon orthodox scholarship and capped by praise for latitudinarian bishops. Nor is the book ultimately deistic, which it is often classed as, for the Gospel is a "revelation of a mystery": mystery not in the sense of "darkness and difficulty" but the clear light of "the salvation of mankind" through the "Gospel and preaching of Jesus Christ." 66

What, then, can replace the sorry charade of priestly corruption? Howard returns to the Lutheran fundamental, the priesthood of all believers: the church is nothing other than the body of its believers. Borrowing a term from the conciliarist tradition, he speaks of the church "diffusive": it is the whole congregation and not its officers or institutions. "A man must be his own expositor, minister, bishop, and council," and "work out his own salvation." In clerical Christianity, the "people" are "called the laity," but in fact there is no essential distinction from the clergy. Christ's mission was to redeem us from a darkness bred of occult mysteries and ceremonies. Christ is the enemy of intricacy: "there was nothing proposed to be believed or done, [but] that was plain to be understood." The gospels and epistles are "plain." Through them there can be achieved an epiphany of the purified intellect. "By the help and light of the Gospel, some have broken these fetters, and stepped into the freedom of reason." Yet it does not follow that there shall be no clergy in such a religion. A reformed clergy, stripped of metaphysical theology and coercive authority, those instruments of mental and physical slavery, will be devoted to two requisites: the perfecting of the texts and translations of Scripture and the teaching of moral virtue. Christian knowledge is neither "born" in us, nor "infused", and there is a "necessity" of learned teachers. Thus, philology and ethics are the proper vocations of Christian teachers. ${ }^{67}$

In his subsequent vindication of his book, Howard distances himself from the deist Blount, and insists, against his critics, that his book does not undermine revelation. He makes a decisive move by insisting - and surely here he echoes Locke's Reasonableness - that "the precepts of the Christian religion, are moral precepts, and obvious to natural reason; but the sanctions and enforcement of them [are] by future retributions, that is divine, revealed from heaven, and confirmed by miracles." ${ }^{68}$ With Locke, he holds that Christian revelation is the guarantor of morality, both epistemically and motivationally. Placing himself firmly within the fold of low churchmanship, he calls his defence a "twofold" vindication, because it upholds not only his own book against the charge of deism, but the reputations of Archbishop Tillotson and Bishop Burnet, from the onslaughts of high churchmen. ${ }^{69}$

We turn to one final text. A book constantly allied with Locke's Reasonableness, and predictably condemned as semi-deistic, was the anonymous A Lady's Religion (1697). Written by a "divine of the Church of England," who was almost certainly William Stephens, the tract is dedicated to Lady Howard, wife of Sir Robert. ${ }^{70}$ It was destined to have a successful career in the eighteenth century, having seven further editions down to 1796. The first edition came from the stable of the arch-Whig publisher Richard Baldwin and the second, of 1704, from Locke's publisher Awnsham Churchill. Meanwhile, the translator of Locke's works, Pierre Coste, put it into French in 1698 as La Religion des Dames, and then, in 1715, appended it to his translation of Locke's Reasonableness, including it in the second volume alongside the Vindications of the Reasonableness, and there it remained in two further editions in 1731 and 1740, bibliographically yoked to Locke's own books. ${ }^{71}$ 
A Lady's Religion is a popularisation of the Reasonableness, rendering it into something Locke never achieved, or aimed at, a devotional tract, in the genre which contemporaries called "practical divinity." Although it lambastes the "designing priesthood" it mostly avoids polemic and is a polite and expressly non-academic essay almost wholly devoid of citation and of anything that looks like a creed. Its anchor is that Christianity is "plain, short, and intelligible." The vanity and vacuity of learned, speculative theology is constantly contrasted with the simplicity of Christ's message, which aimed only to improve the moral life, and must be graspable by "the poor day-labourer" (echoing here a famous phrase of Locke's). ${ }^{72}$ The Gospel offers three essentials: a narrative of the fact of Christ's mission, a declaration of the moral law, and "a revelation of such motives which are proper to enforce this law upon our minds". The tract is keenly averse to formal devotion, scarcely even allowing set times or forms of prayer, for "we are apt to turn forms into formalities." Lady Howard's seeking of guidance in preparing for the eucharistic sacrament is more or less brushed aside. Rather, prayer and devotion must imbue ordinary conduct, "the common offices of life," and should be "occasional" (that is, fitted to occasions) and circumstantial. After all, the common person has simply no capacity to retrieve time in the day for elaborate religion, but yet may be prayerful "without hindering the constant work of his calling". Prayer consists not in "formal petitions" but in habitude, in manner of conduct. ${ }^{73}$

In making us all priests of the quotidian, the Lockeans rendered redundant the idolatry of supposing that priesthood belongs to particular persons, places, or performances. There shall be public worship, for it is natural collectively to express homage to God. And there shall be a clergy set aside, but its task shall be hortatory and scholarly. Just as the natural philosopher shall bring to light the revelation of God's works in Creation, so the Christian minister shall clarify the revelation of God's words in Scripture. There was, among the Lockeans, no movement against Christianity, not even, on the whole, against the Church of England; but, rather, an equidistancing from deism on the one hand, hyper-clericalism on the second, and sectarian incivility on the third. For all their historical and anthropological flights, their universalising of the critique of priesthoods, and their deployment of a new, fashionable word, their immediate polemical locale lies within the domain of the Church politics of postRevolution England. The attack on priestcraft was a prelude to Church Whiggism, and the radicalism of the critique belies the conservatism of its ecclesiastical outcome. In Stephens and Howard, as in Locke, we find Whig authors engaged in domesticating anti-clericalism within the verge of latitudinarian churchmanship, and thereby serving the defence of the Toleration Act and of the Revolution itself, of which many Anglican clergy remained deeply suspicious and resentful. It is misleading, therefore, to assume that the cry of 'priestcraft' was the weapon uniquely of deists and that it portended the dissolution of the Christian church. Locke lived and died a conforming and practising member of the Church of England. If we today find irresistible the tug toward conceiving of Locke's era as that of the early Enlightenment, it may prove salutary to consider it as no less belonging to the long Reformation. 
${ }^{1}$ For context, see Champion, Pillars of Priestcraft Shaken; Goldie, "Priestcraft and the Birth of Whiggism"; Harrison, 'Religion' and the Religions.

${ }^{2}$ The standard modern edition of The Reasonableness of Christianity is Higgins-Biddle's in the Clarendon Edition of the Works of John Locke; hereafter $R C$. The editor's Introduction is an outstanding portrait of Locke's theology. Also: Locke, Vindications of the Reasonableness of Christianity.

${ }^{3}$ Key discussions are: Marshall, "Locke, Socinianism, 'Socinianism', and Unitarianism”; Nouvo, Christianity, Antiquity, and Enlightenment; Snobelen, "Socinianism, Heresy, and John Locke's Reasonableness of Christianity"; Wallace, "Socinianism, Justification by Faith, and the Sources of John Locke's Reasonableness of Christianity"; Wootton, "John Locke: Socinian or Natural Law Theorist?" See Champion, Republican Learning; Sullivan, John Toland and the Deist Controversy.

${ }^{4}$ It is, however, true that theology impacts ecclesiology, so that Locke's Christology will make a difference to his conception of the church and clergy.

${ }^{5}$ See Ashcraft, "Anticlericalism and Authority in Lockean Political Thought."

${ }^{6}$ See Nuovo, "Portrait of John Locke as a Christian Virtuoso" in Christianity, Antiquity, and Enlightenment.

${ }^{7}$ Correspondence of John Locke, letter no. 2775; hereafter cited as 'L' with letter number. For Hardy, see Oxford Dictionary of National Biography and Burden, Biographical Dictionary of Tutors at the Dissenters Private Academies, 1660-1729.

${ }^{8}$ See Hull, Benjamin Furly and Quakerism in Rotterdam; Hutton, ed., Benjamin Furly, 1646-1714.

${ }^{9}$ For a construal of seventeenth-century religious disputes in relation to civility, see Bejan, Mere Civility.

${ }^{10}$ Furly, Worlds Honour Detected.

${ }^{11}$ L1562, L1585, L1672, L1684, L1789.

${ }^{12}$ Locke took a keen interest in the Keithian schism, which is well represented in his library; several scholars are currently at work on this topic.

${ }^{13}$ L1702; cf. L2832, L2889.

${ }^{14}$ L1355, L1745.

${ }^{15}$ L1672, L1684, L1480, L1745, L2629, L2754, L3030. Chemarims: idolatrous priests, from Zephaniah 1: 4. ${ }^{16}$ L1268, L1351, L1371, L1480, L1562, L1745, L2754.

${ }^{17}$ L1268, L1344, L1480, L1650, L2754; Toland, Letters to Serena, 129-30.

${ }^{18}$ Locke's toleration of the Dissenters should not be mistaken for approval of them; "tolerance" was simply that.

${ }^{19}$ L1614. An echo of Mathew 23: 15.

${ }^{20}$ L1480, L1585, L1702.

${ }^{21}$ Historical Manuscripts Commission, Buccleuch, ii. 798.

${ }^{22}$ L1480. Marsham, Chronicus Canon Aegyptiacus; Spencer, De Legibus Hebraeorum.

${ }^{23}$ L1480, L1533. Luke 22: 15-20. See Parker, Codex Bezae; Billings, Do This in Remembrance of Me.

${ }^{24}$ For the embedment of "radical" critiques of religion in orthodox Christian scholarship, see Levitin, Ancient Wisdom in the Age of the New Science.

${ }^{25}$ British Library, Add. MS 8888, fos. 100-9. See Robbins, “Absolute Liberty”.

${ }^{26}$ For the Boyle Lectures, see Jacob, Newtonians.

${ }^{27}$ L1630. Le Catechisme des Pietistes by "Graviset" (probably Paul Gravisset): book not traced.

${ }^{28}$ L1851; Fletcher, Political Works, 58-9.

${ }^{29}$ Paknadel, "Shaftesbury's Illustrations of Characteristics."

${ }^{30}$ Masham, Discourse, 124.

${ }^{31} R C, 143,162$.

${ }^{32} R C, 6,147,159,169-70$; cf. 108, 138.

${ }^{33}$ Vindications of the $R C, 12,77$.

${ }^{34} R C, 38,77,102$.

${ }^{35}$ On the messianic secret, see Nuovo, Christianity, Chap. 5.

${ }^{36} R C, 45-6,50,84-7,89,92$.

${ }^{37} R C, 92,143-4,147,149,162$.

${ }^{38}$ Locke, Political Essays, 344.

${ }^{39}$ Rousseau, Social Contract, Book 4, Chap. 8.

${ }^{40}$ His objection to Catholicism, however, rests on its violation of the canons of citizenship.

${ }^{41}$ Vindications of the $R C, 232$.

${ }^{42} R C, 23,33$.

${ }^{43}$ See Davis, "Against Formality."

${ }^{44} R C, 160$.

${ }^{45} R C, 147$.

${ }^{46} R C, 160 ; 1$ Corinthians 14: 26.

${ }^{47}$ Locke, Political Essays, 345.

${ }^{48}$ Locke, Two Tracts on Government, 216. See Rose, "John Locke." 
${ }^{49}$ Edwards, Brief Vindication, sig. A4r; Edwards, Socinian Creed, 125.

${ }^{50}$ Anonymous, Free but Modest Censure, 11.

${ }^{51}$ It is possible that several authors contributed; I here treat Willis as sole author.

${ }^{52}$ Vindications of the RC, 231.

${ }^{53}$ Willis, Occasional Paper, no. 1: 21, 30; no. 4: 26; no. 5: 39-40; $R C, 143,147,149$. Space here precludes consideration of Tindal's tract, or of a pamphlet of 1702, John Dennis's The Danger of Priestcraft to Religion and Government, both of which Locke owned: Harrison and Laslett, Library of John Locke, nos. 2388, 2927.

54 "I do not remember that he [Jesus] anywhere assumes to himself the title of a priest, or mentions anything relating to his priesthood": $R C, 120$.

${ }^{55}$ Willis, Occasional Paper, no. 5: 4-5, and passim; no. 7: 4.

${ }^{56}$ Edwards, Socinian Creed, 246, 260, 263.

${ }^{57}$ Oxford Dictionary of National Biography; Voitle, Third Earl of Shaftesbury, 111, 170, 251-3, 271; Goldie, ed., The Reception of Locke's Politics, vol. 1, 301-13.

${ }^{58}$ Stephens, Account, 4, 10, 13, 30. Copy in Locke's library: no. 937.

${ }^{59}$ Ibid., 6, 24-6.

${ }^{60}$ Ibid., 10, 21, 23, 30 .

${ }^{61}$ Hale, Contemplations, which had been published in 1676. See Cromartie, Sir Matthew Hale, 1609-1676, Chaps. $10 \& 11$.

${ }^{62}$ Stephens, Account, 18-19; Francis Atterbury, The Scorner ... a Sermon ... at Whitehall (1694). For Atterbury, see Bennett, Tory Crisis.

${ }^{63}$ Marvell, Short Historical Essay, in Prose Works, vol. 2, 150ff.

${ }^{64}$ Howard, History of Religion, xiii-xiv, 10, 38-9, 76, 84, 93, and passim.

${ }^{65}$ Ibid., xiv, 4, 9, 11, 16, 29, 36, 38, 47, 56, 75, 78; Howard, Twofold Vindication, 113, 124. Copies in Locke's library: nos. $1525 \mathrm{a}, 2908$.

${ }^{66}$ Howard, History, 60-1.

${ }^{67}$ Ibid., xi, 40, 58, 63, 68, 118, and passim.

${ }^{68}$ Howard, Twofold Vindication, 166.

69 'High', 'Low', and 'latitudinarian' are not, I think, mirages, in post-Revolution church politics. The best recent accounts of the Church of England in this period are: Bulman, Anglican Enlightenment, and Sirota, Christian Monitors.

${ }^{70}$ Attributed to Stephens by Pierre Coste in his 1715 translation. Copies (English and French) in Locke's library: nos. 1652-4.

${ }^{71}$ See Yolton, John Locke Bibliography, 285-90.

${ }^{72} R C, 170$.

${ }^{73}$ Stephens, Lady's Religion, sigs. A2v; 16, 21, 36-7, 46, 60.

\section{Bibliography}

Anonymous. A Free but Modest Censure. London, 1697.

Ashcraft, Richard. "Anticlericalism and Authority in Lockean Political Thought." In The Margins of Orthodoxy: Heterodox Writing and Cultural Response, 1660-1750, edited by Roger D. Lund, 73-96. Cambridge: Cambridge University Press, 1995.

Atterbury, Francis. The Scorner ... a Sermon ... at Whitehall. London, 1694.

Bejan, Teresa M. Mere Civility: Disagreement and the Limits of Toleration. Cambridge, MA: Harvard University Press, 2017.

Bennett, G. V. The Tory Crisis in Church and State, 1688-1730. Oxford: Clarendon Press, 1975.

Billings, Bradley S. Do This in Remembrance of Me: The Disputed Words in the Lukan Institution. London: A\&C Black, 2006.

Bulman, William. Anglican Enlightenment: Orientalism, Religion, and Politics in England and its Empire, 1648-1715. Cambridge: Cambridge University Press, 2015. 
Burden, M. A Biographical Dictionary of Tutors at the Dissenters' Private Academies, 16601729 (2013): http://www.qmulreligionandliterature.co.uk/online-publications/abiographical-dictionary/.

Champion, Justin. The Pillars of Priestcraft Shaken: The Church of England and Its Enemies 1660-1730. Cambridge: Cambridge University Press, 1992.

Champion, Justin. Republican Learning: John Toland and the Crisis of Christian Culture, 1696-1722. Manchester: Manchester University Press, 2003.

Cromartie, Alan. Sir Matthew Hale, 1609-1676. Cambridge: Cambridge University Press, 1995.

Davis, J. C. "Against Formality: One Aspect of the English Revolution.” Transactions of the Royal Historical Society 3 (1993): 265-88.

Edwards, John. A Brief Vindication of the Fundamental Articles of the Christian Faith. London, 1697.

Edwards, John. The Socinian Creed. London, 1697.

Fletcher, Andrew. Political Works, edited by John Robertson. Cambridge: Cambridge University Press, 1997.

Furly, Benjamin. The Worlds Honour Detected. 1663.

Goldie, Mark. "Priestcraft and the Birth of Whiggism." In Political Discourse in Early Modern Britain, edited by Nicholas Phillipson and Quentin Skinner, 209-231.

Cambridge: Cambridge University Press, 1993.

Goldie, Mark, ed. The Reception of Locke's Politics, 6 vols. London: Pickering \& Chatto, 1999.

Hale, Matthew. Contemplations Moral and Divine. London, 1676.

Harrison, John, and Peter Laslett. The Library of John Locke. Oxford: Clarendon Press, 1971.

Harrison, Peter. 'Religion' and the Religions in the English Enlightenment. Cambridge: Cambridge University Press, 1990.

Howard, Robert. The History of Religion. London, 1694.

Howard, Robert. A Twofold Vindication. London, 1696.

Hull, William I. Benjamin Furly and Quakerism in Rotterdam. Swarthmore, PA: Swarthmore College, 1941.

Hutton, Sarah, ed. Benjamin Furly, 1646-1714: A Quaker Merchant and his Milieu. Florence: Olschki, 2007.

Jacob, Margaret C. The Newtonians and the English Revolution, 1689-1720. Cornell: Cornell University Press, 1976.

Levitin, Dmitri. Ancient Wisdom in the Age of the New Science: Histories of Philosophy in England, c. 1640-1700. Cambridge: Cambridge University Press, 2015.

Locke, John, The Correspondence of John Locke, ed. E. S. de Beer, 8 vols. Oxford: Clarendon Press, 1976-89.

Locke, John. Political Essays, edited by Mark Goldie. Cambridge: Cambridge University Press, 1997.

Locke, John. The Reasonableness of Christianity, edited by John C. Higgins-Biddle. Oxford: Clarendon Press, 1999. 
Locke, John. Two Tracts on Government, edited by Philip Abrams. Cambridge: Cambridge University Press, 1967.

Locke, John. Vindications of the Reasonableness of Christianity, edited by Victor Nuovo.

Oxford: Clarendon Press, 2012.

Marshall, John. 'Locke, Socinianism, 'Socinianism', and Unitarianism.” In English

Philosophy in the Age of Locke, edited by M. A. Stewart, 111-82. Oxford: Clarendon Press, 2000.

Marsham, John. Chronicus Canon Aegyptiacus. London, 1672.

Marvell, Andrew. A Short Historical Essay Concerning General Councils, Creeds, and Impositions (1676). In Prose Works, edited by A. Patterson, et al., 2 vols. New Haven: Yale University Press, 2003.

Masham, Damaris. A Discourse Concerning the Love of God. London, 1696.

Nuovo, Victor. Christianity, Antiquity, and Enlightenment: Interpretations of Locke. Dordrecht: Springer, 2011.

Paknadel, F. "Shaftesbury's Illustrations of Characteristics." Journal of the Warburg and Courtauld Institutes 37 (1974): 290-312.

Parker, David C. Codex Bezae. Cambridge: Cambridge University Press, 1992.

Robbins, Caroline. "Absolute Liberty: The Life and Thought of William Popple, 1638-1708." William and Mary Quarterly 24 (1967): 190-223.

Rose, Jacqueline. "John Locke, 'Matters Indifferent', and the Restoration Church of England." Historical Journal 48 (2005): 601-21.

Sirota, Brent. The Christian Monitors: the Church of England in the Age of Benevolence, 1680-1730. New Haven: Yale University Press, 2014.

Snobelen, Stephen D. “Socinianism, Heresy, and John Locke's Reasonableness of Christianity." Enlightenment and Dissent 20 (2001): 88-125.

Spencer, John. De Legibus Hebraeorum. London, 1683-5.

Stephens, William. An Account of the Growth of Deism. London, 1696.

Stephens, William. A Lady's Religion. London, 1696.

Sullivan, R. E. John Toland and the Deist Controversy. Cambridge, MA: Harvard University Press, 1982.

Toland, John. Letters to Serena. London, 1704.

Voitle, Robert. The Third Earl of Shaftesbury. Baton Rouge: Louisiana State University Press, 1984.

Wallace, D. D. "Socinianism, Justification by Faith, and the Sources of John Locke's Reasonableness of Christianity." Journal of the History of Ideas 45 (1984): 49-66.

Willis, Richard. The Occasional Paper. London, 1697-8.

Wootton, David. "John Locke: Socinian or Natural Law Theorist?" In Religion, Secularization, and Political Thought: Thomas Hobbes to J. S. Mill, edited by James E. Crimmins, 79-88. London: Routledge, 1989.

Yolton, Jean. John Locke: A Descriptive Bibliography. Bristol: Thoemmes Press, 1998. 